\title{
Erratum to: Exploring Perceptual Skills in Children with Autism Spectrum Disorders: From Target Detection to Dynamic Perceptual Discrimination
}

\author{
Louisa Miller • Maggie McGonigle-Chalmers
}

Published online: 10 November 2013

(C) Springer Science+Business Media New York 2013

\section{Erratum to: J Autism Dev Disord}

\section{DOI 10.1007/s10803-013-1977-6}

There is an error in the last row of the Table 1 in the original publication of the article. The corrected version of the Table 1 has been presented with this erratum.

Table 1 Description of each of the five tasks

\begin{tabular}{|c|c|c|c|c|}
\hline Task & Task requirement & $\begin{array}{l}\text { Description of stimuli } \\
\text { (jungle background always present) }\end{array}$ & $\begin{array}{l}\text { Task-specific dependent } \\
\text { variable }\end{array}$ & Example screenshot \\
\hline Centre detection & $\begin{array}{l}\text { Press the predefined button as } \\
\text { soon as the tiger appears }\end{array}$ & One tiger in centre of screen & $\begin{array}{l}\text { Time to stimulus onset }(500, \\
1,000,2,000 \mathrm{~ms})\end{array}$ & \\
\hline Side detection & $\begin{array}{l}\text { Press the button on the same side } \\
\text { as the tiger as soon as it appears }\end{array}$ & $\begin{array}{l}\text { One tiger in vertical centre, positioned midway } \\
\text { between the centre and the right or left edge }\end{array}$ & Size (small, medium, large) & \\
\hline $\begin{array}{l}\text { Static } \\
\text { discrimination }\end{array}$ & $\begin{array}{l}\text { Press the button on the same side } \\
\text { as the largest tiger }\end{array}$ & $\begin{array}{l}\text { Two tigers of differing sizes positioned as } \\
\text { above }\end{array}$ & $\begin{array}{l}\text { Size difference (small vs. } \\
\text { large, small vs. medium, } \\
\text { medium vs. large) }\end{array}$ & \\
\hline $\begin{array}{l}\text { Single dynamic } \\
\text { change } \\
\text { detection }\end{array}$ & $\begin{array}{l}\text { Press the button on the same side } \\
\text { as the tiger as soon as it begins } \\
\text { to accelerate }\end{array}$ & $\begin{array}{l}\text { One tiger positioned as for side. Tiger } \\
\text { approaches at a constant speed and then } \\
\text { accelerates }\end{array}$ & $\begin{array}{l}\text { Initial speed, acceleration, } \\
\text { acceleration rate }\end{array}$ & See side detection \\
\hline $\begin{array}{l}\text { Dynamic } \\
\text { discrimination }\end{array}$ & $\begin{array}{l}\text { Press the button on the same side } \\
\text { as the faster tiger }\end{array}$ & $\begin{array}{l}\text { Two tigers, one each in right and left positions. } \\
\text { Both approach at the same initial speed then } \\
\text { one accelerates }\end{array}$ & $\begin{array}{l}\text { Initial speed, acceleration, } \\
\text { acceleration rate }\end{array}$ & $\begin{array}{l}\text { See static } \\
\text { discrimination }\end{array}$ \\
\hline
\end{tabular}

The online version of the original article can be found under doi:10.1007/s10803-013-1977-6.

L. Miller $(\varangle) \cdot$ M. McGonigle-Chalmers

Department of Psychology, School of Philosophy, Psychology

and Language Sciences, University of Edinburgh, 7 George

Square, Edinburgh EH8 9JZ, UK

e-mail: s0452198@sms.ed.ac.uk; L.Miller-8@sms.ed.ac.uk 